\title{
COXEN Score 29
}

National Cancer Institute

\section{Source}

National Cancer Institute. COXEN Score 29. NCI Thesaurus. Code C128226.

A score of 29 on the COXEN Sensitivity Scale. 